\title{
Pemberdayaan Perempuan Kelompok UKM di Desa Jetis Kecamatan Bandungan Kabupaten Semarang
}

\author{
Arif Hidayat, Pujiono, Saru Arifin, Laga Sugiarto \\ Universitas Negeri Semarang, Indonesia \\ arifhidayat@mail.unnes.ac.id
}

Received: $4^{\text {th }}$ February $2020 \mid$ Accepted: $27^{\text {th }}$ July 2020 | Publihsed: $20^{\text {th }}$ August 2020

\section{Key word:}

Economic

Empowerment;

SMEs;

Women

entrepreneurs

\section{Kata Kunci}

Pemberdayaan

Ekonomi;

UKM:

Pelaku usaha perempuan

\section{Abstract}

Jetis Village has SMEs that are engaged in modeste (sewing and embroidery) which are still implemented with conventional systems in terms of production, management and marketing. This makes SME Partners have some security when they have to face the big order season or when they have to compete with other similar SMEs that have developed modern management. UKM players who are mostly the attention in this service. This service method is 1) Observation; 2) Focus Group Discussions; 3) Dissemination; and 4) Evaluation. The results of this service are 1) activities focused on partner networking, managerial strengthening, and online marketing training through social media; 2) SME Partners understand the managerial processes that are recorded and monitored starting from financial managerial, human resources, and production raw materials; 3) SME Partners are facilitated by related agencies to have networks with raw material suppliers and potential market candidates; 4) SME Partners own and are able to assist Facebook Pages which are used for online marketing.

\section{Abstrak}

Desa Jetis memiliki UKM yang bergerak di bidang modeste (jahit dan bordir) yang masih dilaksanakan dengan sistem konvensional baik produksi, pengelolaan, ataupun pemasaran. Hal ini menjadikan UKM Mitra memiliki beberapa kendala saat harus menghadapi musim pesanan besar atau saat harus bersaing dengan UKM sejenis lainnya yang sudah mengembangkan pengelolaanya secara modern. Pelaku UKM yang sebagian besar perempuan menjadi perhatian dalam pengabdian ini. Metode pengabdian ini adalah 1) Observasi; 2) Focus Group Discussion; 3) Diseminasi; dan 4) Evaluasi. Hasil pengabdian ini adalah 1) kegiatan yang difokuskan adalah penguatan jejaring mitra, penguatan manajerial, dan pelatihan pemasaran online melalui media sosial; 2) UKM Mitra memahami proses manajerial yang tercatat dan terpantau mulai dari manajerial keuangan, SDM, dan bahan baku produksi; 3) UKM Mitra difasilitasi oleh dinas terkait memiliki jejaring dengan penyedia bahan baku dan calon pasar potensial; 4) UKM Mitra memiliki dan mampu mengelola Facebook Page yang digunakan sebagai sarana pemasaran online. 


\section{PENDAHULUAN}

Pelaku usaha di Indonesia masih didominasi oleh UKM yakni sebesar $99,99 \%$ dari total unit usaha atau sebesar 53,8 juta unit usaha yang terdiri dari 53,2 juta unit usaha mikro, 573,6 ribu unit usaha kecil dan 42,6 ribu unit usaha menengah. Secara sektoral, jumlah UKM pada sektor pertanian paling dominan yakni sebesar 49,6\%, hal ini sejalan dengan serapan tenaga kerjanya yang berjumlah $43,0 \%$ dari total tenaga kerja. Sebesar lebih dari $60 \%$ pekerja UKM adalah perempuan (Indiworo, 2016). Oleh karena itu, perlu adanya inovasi dalam pengembangan dan pemasaran ramah gender. Pemicu lainnya yang tak kalah penting adalah belum sinkronnya kebijakan yang dibuat antar institusi baik di tingkat pusat maupun di tingkat daerah. Berbagai upaya telah dilakukan oleh berbagai pihak termasuk pemerintah melalui kementerian, dinas terkait, maupun pemerhati UKM baik lembaga maupun individu (Hanim, 2015).

\section{Usaha Kecil Mikro (UKM)} diklasifikasikan dalam empat kelompok, yaitu: (i) UKM sektor informal, contohnya pedagang kaki lima; (ii) UKM Mikro adalah para UMKM dengan kemampuan sifat pengrajin namun kurang memiliki jiwa kewirausahaan untuk mengembangkan usahanya; (iii) Usaha
Kecil Dinamis adalah kelompok UKM yang mampu berwirausaha dengan menjalin kerjasama (menerima pekerjaan sub kontrak) dan ekspor; dan (iv) Fast Moving Enterprise adalah UKM yang mempunyai kewirausahaan yang cakap dan telah siap bertransformasi menjadi usaha besar. UKM pada umumnya bersifat income gathering yaitu menaikkan pendapatan, dengan ciri-ciri sebagai berikut: (i) merupakan usaha milik keluarga; (ii) menggunakan teknologi yang masih relatif sederhana; (iii) kurang memiliki akses permodalan (bankable); dan (iv) tidak ada pemisahan modal usaha dengan kebutuhan pribadi.

Micro Enterprise, merupakan Usaha Kecil Menengah yang memiliki sifat pengrajin tetapi belum memiliki sifat kewirausahaan. Hal ini terjadi karena umumnya UMKM bersifat income gathering yaitu menaikkan pendapatan, dengan ciri-ciri sebagai berikut: merupakan usaha milik keluarga, menggunakan teknologi yang masih relatif sederhana, kurang memiliki akses permodalan (bankable), dan tidak ada pemisahan modal usaha dengan kebutuhan pribadi. Micro Enterprise, merupakan Usaha Kecil Menengah yang memiliki sifat pengrajin tetapi belum memiliki sifat kewirausahaan (Sedyastuti, 2018).

Kondisi ekonomi dan teknologi 
informasi yang sangat cepat dalam satu dasawarsa terakhir utamanya dalam menyambut Masyarakat Ekonomi ASEAN. Kondisi ini menuntut pelaku UKM untuk menangkap peluang dalam memasarkan produk dan mengembangkan usahanya. Oleh karena itu, pemasaran hasil UMKM tidak hanya dilakukan secara konvensional dengan melakukan strategi pemasaran di lapangan, tetapi juga harus mulai menggunakan media pemasaran modern berbasis toko online (Saputra, 2015).

Berdasarkan data dari Badan Pusat Statistik (2016), lebih dari 77\% masyarakat memilih mencari informasi di internet sebelum memutuskan membeli suatu barang. Keefektifan waktu menjadi salah satu pertimbangan masyarakat dalam memperoleh informasi melalui internet. Tidak jarang masyarakat lebih memilih belanja secara online ketika harga dan sepesifikasi barang yang ditawarkan melalui internet cenderung lebih murah dibanding dengan harga yang ada di pasaran.

Kondisi ini ditangkap sebagai peluang oleh para pelaku UKM dalam mengembangkan bisnisnya, salah satunya dengan membuat website jual beli online. Hal ini didasari oleh meningkatnya pengguna internet sehingga memudahkan para pebisnis dalam memasarkan dan mengembangkan lahan bisnisnya.

Desa Jetis adalah salah satu desa dari 9 desa dan 1 kelurahan yang berada wiliayah Kecamatan Bandungan Kabupaten Semarang, dengan luas wilayah 2,79 $\mathrm{km}^{2}$. Penduduk desa Jetis berjumlah 4521 jiwa dari 1327 KK yang tersebar di 7 dusun. Tercatat 104 KK sebagai keluarga miskin, dan mayoritas penduduknya lulusan SD dan SLTP (BPS Semarang, 2016). Lapangan usaha utama mayoritas penduduk di Desa Jetis adalah sektor pertanian pangan dan holtikultura, industri kecil, dan perdagangan.

Khusus lapangan kerja sektor industri ini, terus mengalami peningkatan, dari 1.262 orang pada tahun 2015 menjadi 1.283 pada tahun 2016 (BPS Semarang, 2015). Salah satu dari industri kecil yang ada bergerak di bidang industri modeste (jahit dan bordir). Desa Jetis merupakan sentra produksi jahit dan bordir, di Dusun Ngawinan saja hampir semua ibu rumah tangga, pemuda dan pemudinya melakukan usaha Jahit dan Bordir. Kelompok UKM "Jahit Mandiri" ini dapat diklasifikasikan sebagai UKM Mikro yang terdiri dari 5 Usaha Dagang bidang jahit dan bordir di Dusun Ngawinan, yaitu Aisyah Bordir (11 pekerja), Dahlia Indah Bordir (6 pekerja), Fazira Collection (7 pekerja), Nazla Collection (5 pekerja), dan Nazira 
Collection (4 pekerja). Industri jahit dan bordir yang dilakukan dianggap mampu meningkatkan kehidupan sosial ekonomi dan menyerap tenaga kerja.

Kelompok UKM "Jahit Mandiri" dibentuk demi memenuhi keinginan pasar yang terus berkembang dan membutuhkan inovasi. Prospek cerah sektor usaha modiste ini memiliki omzet penjualan bisa mencapai 10 juta rupiah dalam sebulan. Para pekerja sesuai dengan bagian kerjanya mendapatkan upah harian, antara Rp50,000 sampai Rp75,000 per harinya, dan jika banyak pesanan menggunakan sistem upah borongan. Permintaan produk jahit dan bordir berupa pakaian senantiasa mengalami peningkatan terutama menjelang perayaan hari besar umat Islam yaitu pada Idul Fitri dan Idul Adha.

Produk-produk selain pakaian seperti louper, bedcover, penunjang alat makan dan lain-lain juga banyak dipesan, meskipun masih sebatas konsumen lokal. Namun demikian, masih banyak hal yang menjadi kendala bagi kelompok mitra, antara lain: keterbatasan akses modal dan informasi pasar, rendahnya SDM dalam penguasaan ilmu pengetahuan serta teknologi, termasuk keterbatasan kemampuan memanfaatkan IT.

Kendala lain yang dihadapi mitra adalah keterkaitan dengan prospek usaha yang kurang jelas serta perencanaan, visi dan misi yang belum mantap.

Pemberdayaan ekonomi masyarakat adalah penguatan pemilikan faktor-faktor produksi, penguatan penguasaan distribusi dan pemasaran, penguatan masyarakat untuk mendapatkan gaji/upah yang memadai, dan penguatan masyarakat untuk memperoleh informasi, pengetahuan dan ketrampilan, yang harus dilakukan secara multi aspek, baik dari aspek masyarakatnya sendiri, mapun aspek kebijakannya (Friedmann, 1992).

Kegiatan ini dimaksudkan untuk melakukan optimalisasi pengembangan usaha bagi Kelompok UKM "Jahit Mandiri" di Desa Jetis Kecamatan Bandungan Kabupaten Semarang khususnya yang digerakkan oleh para pekerja perempuan.

Berdasarkan uraian pada analisis situasi yang telah teridentifikasikan, bahwa perkembangan teknologi, informasi dan telekomunikasi serta terjadinya pergeseran gaya beli yang ada di masyarakat mendorong UKM konvensional untuk lebih modern dan berdaya. Oleh karena itu diperlukan upaya pemberdayaan dengan memberikan pelatihan soft skill bagi pelaku UKM dalam memasarkan produknya melalui pemanfaatan IT.

Mitra kegiatan pengabdian mengenai pemberdayaan ekonomi berwawasan 
hukum dan konservasi ini adalah Kelompok UKM "Jahit Mandiri" Desa Jetis Kecamatan Bandungan Kabupaten Semarang (selanjutnya disebut UKM mitra), yang dipimpin oleh H. Saifu Nadzir.

\section{METODE}

Metode yang digunakan pada pelaksanaan kegiatan ini adalah bimbingan dan penyuluhan dengan tahapan sebagai berikut:

a. Observasi dan Survey. Kegiatan pada tahap ini adalah membangun kesepahaman dengan pihak terkait (Stakeholders) dengan rencana kegiatan : Kunjungan lapangan; Memproses perizinan; Koordinasi dengan pihak UMKM Center, dan Dinas Koperasi, UMKM, Perindustrian dan Perdagangan Kabupaten Semarang. Partisipasi mitra pada tahap ini adalah Memberikan ijin dan informasi awal mengenai pokok kegiatan (Need Assestment) dengan luaran Mendapat izin, kepastian waktu dan tempat kegiatan, serta kebutuhan metode, materi, maupun bahan dan peralatan

b. Focus Group Discussion, Prosedur kerjan pada tahap ini adalah Brainstorming: Diskusi permasalahan mitra, potensi dan daya dukung lainnya. Rencana kegiatan :
Medokumentasikan data primer dan sekunder permasalahan dan potensi mitra UKM Desa Jetis; Mendiskusikan program pemerintah, dan UMKM Center dalam mendorong UKM "ramah gender". Partisipasi mitra pada tahap ini adalah Menjadi peserta aktif dalam diskusi, dan menyediakan tempat FGD, dan membantu kelancaran FGD, serta mengundang stakeholders. dengan luaran Memperoleh data konkret persoalan dan potensi mitra dan potensi serta daya dukung lingkungan, sosial \& budaya, maupun kebijakan dan program pemerintah

c. Desiminasi, Prosedur kerjanya adalah Tahap Pelaksanaan: Tim pengabdian berkoordinasi untuk persiapan materi dengan rencana kegiatan : Peningkatan Kapasitas SDM (materi kriteria UKM "ramah gender”), Pengembangan Jejaring Mitra (materi kebijakan dan program pemerintah/ UMKM Center). Partisipasi mitra pada tahap ini adalah Keterlibatan aktif mitra, dan seluruh anggota kelompok UKM dalam kegiatan, serta menyiapkan tempat kegiatan dengan luaran Pemahaman mitra mengenai "Kriteria UKM berbasis gender" dan berbagai kebijakan dan program 
pemerintah/UMKM Center

d. Evaluasi, Prosedur kerjanya adalah Tahap Monev: Tim persiapkan instrumen monev dengan rencana kegiatan: Monev kegiatan peningkatan pemahaman \& kesiapan mitra UKM . Partisipasi mitra pada tahap ini adalah Keterlibatan aktif mitra, dan seluruh anggota kelompok UKM dalam kegiatan dengan luaran Kesiapan mitra menjadi UKM "ramah gender"dan rencana tindak lanjut (RTL)

Sasaran dalam kegiatan pengabdian ini adalah seluruh anggota UKM "Jahit Mandiri” Desa Jetis Kecamatan Bandungan Kabupaten Semarang, sebanyak 30 orang yang bergerak dalam usaha jahit dan bordir

\section{HASIL}

Kegiatan pengabdian di Desa Jetis yang dilakukan pada bulan Juni September 2019 menghasilkan beberapa hal sesuai dengan metode pelaksanaan kegiatan sebagai berikut:

a. Observasi dan Survey. Hasil survey dan observasi yang dilakukan pada 18 Juni 2019 terhadap UKM Mitra menghasilkan hal-hal sebagai berikut:

- Program pengembangan usaha "ramah gender" yang dilakukan UMKM Center serta Dinas
Koperasi, UMKM, Perindustrian dan Perdagangan Kabupaten Semarang masih perlu perbaikan dan penyempurnaan.

- Program pembinaan yang masih diprioritaskan pada peningkatan kualitas dan kuantitas produksi juga perlu mendapat perhatian.

- Sebagian besar mitra UKM, dalam usahanya masih belum memiliki minat dan kesiapan dalam pemanfaatan IT sebagai bagian penting pengembangan usahanya yang perlu memperoleh perhatian khusus. Hal ini disebabkan oleh beberapa faktor seperti: (a) minimnya pengetahuan dan ketrampilan di bidang IT; (b) lemahnya aspek manajemen; (c) aspek teknis yang tidak menunjang; serta (d) belum tersedianya sumber pembiayaan yang berorientasi pada pengembangan usaha.

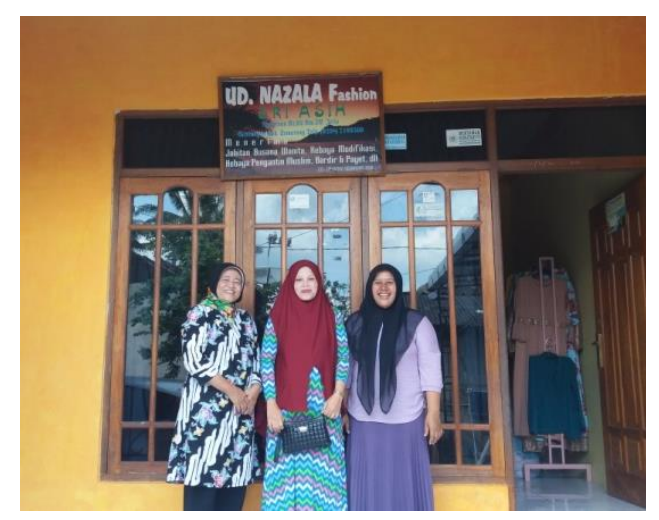

Gambar 1. Survey dan Pra Kondisi

b. Focus Group Discussion yang 
dilakukan pada 21 Juli 2019

menghasilkan beberapa kegiatan-

kegiatan yang disepakati bersama

untuk pengembangan dan

pemberdayaan pelaku UKM Mitra

yang ramah gender di antaranya:

- Peningkatan kapasitas UKM

- Peningkatan Jejaring Mitra

- Pelatihan Pemasaran Online

\section{c. Desiminasi}

Kegiatan diseminasi berupa pemberian materi dan pendampingan kepada UKM Mitra dilakukan pada 25 Agustus 2019.

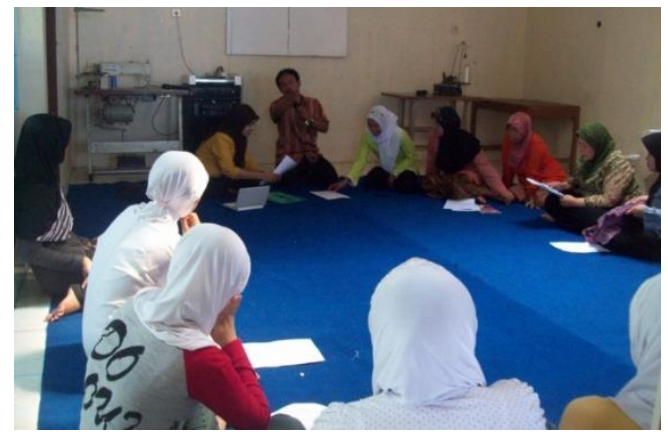

Gambar 2. Kegiatan Diskusi dan

Diseminasi

- Peningkatan Kapasitas UKM.

Pada materi ini, peserta memahami bagaimana melakukan manajerial dalam hal bahan baku, SDM, dan keuangan sehingga para perempuan pelaku UKM Mitra dapat membuat pola manajemen sederhana sehingga tidak kesulitan saat mendapatkan order dalam jumlah besar.

- Peningkatan jejaring mitra, kegiatan ini dijembatani oleh UMKM Center Semarang dan Dinkopperindag dan UMKM Semarang. UKM Mitra mendapat daftar mitra pemasok bahan baku dan bahan pelengkap dalam industry jahit dan bordir. Selain itu UKM Mitra juga dikenalkan dengan jejaring pasar konveksi dan modeste. Pendampingan yang dilakukan oleh Dinas terkait dan UMKM Center memastikan agar UKM Mitra mendapatkan bahan baku b berkualitas baik dan juga calon pangsa pasar yang tepat.

- Pada pelatihan pemasaran online, tim pengabdi menyarankan kepada UKM Mitra agar membuat Facebook Page dan mengunggah produk ke Facebook Page.

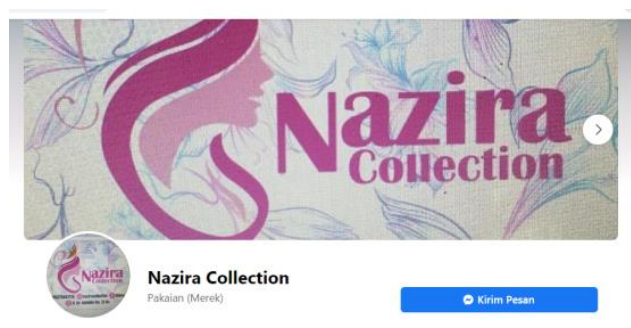

Gambar 3. Salah satu Facebook Page UKM Mitra

\section{d. Evaluasi}

Kegiatan evaluasi yang dilakukan adalah dengan memantau dan memberikan penilaian terhadap 
pemahaman UKM Mitra terhadap materi-materi yang diberikan. Selain itu memastikan UKM Mitra dan jejaring mitra yang dibangun berhubungan dengan baik.

Hal yang menarik pada kegiatan pengabdian ini adalah perempuan penggerak UKM Mitra sangat cepat dalam menyerap dan mempraktikkan ilmu yang didapat. Beberapa UKM yang tergabung dalam UKM Mitra telah memiliki catatan sederhana mengenai keuangan, sistem absen sederhana (ditulis dalam buku), dan pendataan calon pasar potensial.

\section{PEMBAHASAN}

Pemberdayaan adalah upaya yang dilakukan Pemerintah, Pemerintah Daerah, Dunia Usaha, dan Masyarakat secara sinergis dalam bentuk penumbuhan iklim dan pengembangan usaha terhadap UKM sehingga mampu tumbuh dan berkembang menjadi usaha yang tangguh dan mandiri. Iklim Usaha adalah kondisi yang diupayakan Pemerintah dan Pemerintah Daerah untuk memberdayakan UKM secara sinergis melalui penetapan berbagai peraturan perundang-undangan dan kebijakan di berbagai aspek kehidupan ekonomi agar UKM memperoleh pemihakan, kepastian, kesempatan, perlindungan, dan dukungan berusaha yang seluas-luasnya (Yuniasari dkk., 2018).

Pengembangan adalah upaya yang dilakukan oleh Pemerintah, Pemerintah Daerah, Dunia Usaha, dan masyarakat untuk memberdayakan UKM melalui pemberian fasilitas bimbingan, pendampingan dan bantuan perkuatan untuk menumbuhkan dan meningkatkan kemampuan dan daya saing UKM.

Pemberdayaan UKM Mitra diselenggarakan sebagai kesatuan dan pembangunan perekonomian nasional untuk mewujudkan kemakmuran rakyat. Dengan dilandasi asas kekeluargaan, upaya pemberdayaan UKM merupakan bagian dari perekonomian nasional yang diselenggarakan berdasar atas demokrasi ekonomi dengan prinsip kebersamaan, berkelanjutan, berwawasan lingkungan, kemandirian, keseimbangan, kemajuan, dan kesatuan ekonomi nasional untuk kesejahteraan seluruh rakyat Indonesia.

Prinsip-prinsip penguatan dalam pemberdayaan ekonomi kecil, yaitu prinsip keutuhan (holistic), keterpaduan (Integrated), prinsip keberlanjutan/ kelestarian (sustainability), prinsip kebersamaan (colaborative) sehingga dapat pemberdayaan yang diutamakan adalah needs based assistance atau pendampingan berbasis kebutuhan. Selain itu artinya pemberdayaan ekonomi harus 
mempertimbangkan kesesuaian program dengan kondisi khas dari masing-masing UKM (Soemarwoto, 2016). Pemberdayaan yang berkelanjutan merupakan kunci dari berhasilnya program dan menguatkan sociopreneur pada UKM menjadi salah satu kunci keberlanjutan program pemberdayaan (Putri, 2017).

Tahap pelaksanaan pengabdian telah dilakukan di UD. Nazala Collection Dusun Ngawinan Desa Jetis Kecamatan Bandungan, pada hari Ahad, tanggal 25 Agustus 2019 dari Jam 08.00 - 16.00. Peserta diseminasi yang hadir sebanyak 30 orang peserta dari Kelompok UKM "Jahit Mandiri”. Dengan representasi kehadiran peserta yang merupakan pemangku kepentingan menunjukkan keberhasilan kegatan sesuai dengan perencanaan sebelumnya. Kegiatan ini dibuka oleh $\mathrm{H}$. Syaifu Nadzir, Ketua Kelompok UKM Jahit Mandiri, sekaligus sebagai peserta. Ketua UKM dalam sambutannya menyebutkan bahwa prioritas pengembangan usaha UKM Jahit Mandiri akan diarahkan pada program-program peningkatan kesejahteraan anggota yang pro-terhadap keseteraan gender dan kepedulian terhadap perempuan.

Kegiatan pemberdayaan ekonomi ini merupakan manifestasi konkrit kepedulian intelektual yang berasal dari kampus terhadap pemenuhan informasi dan strategi yang dibutuhkan masyarakat desa, khususnya UKM. Setelah pembukaan, para peserta serius mengikuti kegiatan hingga selesai.

Materi pemberdayaan ekonomi, berkaitan dengan pemahaman soft dan hard skill dalam kesiapan para pelaku usaha kecil dan upaya-upaya yang telah atau sedang mereka lakukan untuk beralih dari sistem konvensional menjadi modern dan responsive terhadap tantangan, meliputi:

a. Pemahaman terhadap peran lembaga keuangan serta pemangku kepentingan terkait (Pemerintah Daerah) dalam mendorong dan memfasilitasi UKM;

b. Penanaman kesadaran dan persepsi para pelaku usaha terkait isu lingkungan, ketertarikan, minat, serta memupuk dan mendorong kesiapan para pelaku usaha dan upaya-upaya yang telah atau sedang mereka lakukan untuk beralih dari sistem konvensional lebih modern; dan

c. Upaya inovatif mengatasi kendala manajemen, teknis, aspek pemasaran, maupun aspek yang diperlukan oleh pelaku usaha dalam usaha migrasi dari sistem konvensional ke sistem IT. Hasilnya menunjukkan bahwa kegiatan ini "sangat diperlukan" bagi peningkatan pemahaman peserta dalam pengelolaan usaha kecil. Diketahui bahwa akselerasi IT dan pemasaran 
online bagi UKM sangat penting mengingat era sekarang arus informasi sangat deras dan cepat (Arminsyurita, 2014).

Tahap evaluasi telah dilaksanakan pada hari Minggu, tanggal 5 September 2019. Tahapan ini para anggota UKM diminta untuk menyampaikan masukan yang dapat diberikan untuk kegiatan rencana tindak lanjut dalam kesempatan kegiatan berikutnya.

Evaluasi dilakukan melalui angket untuk melihat urgensi dan manfaat diseminasi. Hasil assessment (Model Rating Scale), menunjukkan bahwa kegiatan ini "sangat diperlukan" bagi peningkatan pemahaman peserta dalam pengelolaan UKM. Bahkan di akhir acara mereka menginginkan kegiatan ini berkelanjutan. Selanjutnya, para anggota UKM diminta untuk menyampaikan masukan yang dapat diberikan untuk kegiatan rencana tindak lanjut dalam kesempatan kegiatan berikutnya.

Hasil evaluasi menunjukkan bahwa UKM membutuhkan:

1. Program fasilitasi dan penyediaan kemudahan dalam formalisasi usaha bagi UKM, melalui pemenuhan hak-hak legal, antara lain dengan menerbitkan surat-surat ijin usaha melalui prosedur dan mekanisme yang sederhana, mudah dan cepat serta tanpa pungutan.
2. Program pengembangan sistem pendukung usaha UKM juga diperlukan, misalnya melalui perluasan sumber pembiayaan, dan penguatan jaringan pasar domestik produk-produk UKM

3. Program penyediaan sistem insentif dan pembinaan untuk memacu pengembangan wirausaha baru UKM.

\section{SIMPULAN}

Kesimpulan dari kegiatan pengabdian masyarakat yang dilakukan adalah:

a) Kegiatan pengabdian ini dilakukan dalam empat tahapan, meliputi: (i) Tahap Prakondisi; (ii) Tahap Brainstorming; (iii) Tahap Pelaksanaan; dan (iv) Tahap Evaluasi. Diseminasi ini secara umum efektif dan tepat sasaran, di mana para peserta serius mengikuti kegiatan hingga selesai. Hasil assessment (Model Rating Scale) menunjukkan bahwa kegiatan ini sangat diperlukan bagi bagi peningkatan pemahaman peserta dalam pengelolaan UKM.

b) Materi pemberdayaan ekonomi, berkaitan dengan pemahaman soft dan hard skill dalam kesiapan para pelaku usaha kecil dan upaya-upaya yang telah atau sedang mereka lakukan untuk beralih dari sistem konvensional 
menjadi lebih modern dan terkelola dengan baik.

c) Materi pemberdayaan ekonomi, meliputi: (i) Pemahaman terhadap peran lembaga keuangan serta pemangku kepentingan terkait (Pemerintah Daerah) dalam mendorong dan memfasilitasi UKM khususnya untuk penguatan jejaring; (ii) Penanaman kesadaran dan persepsi para pelaku usaha terkait isu lingkungan, ketertarikan, minat, serta memupuk dan mendorong kesiapan para pelaku usaha dan upaya-upaya yang telah atau sedang mereka lakukan untuk beralih dari sistem konvensional menjadi "ramah gender"; dan (iii) Upaya inovatif mengatasi kendala manajemen, teknis, aspek pemasaran, maupun aspek yang diperlukan oleh pelaku usaha dalam usaha migrasi dari sistem konvensional ke sistem IT yang ramah lingkungan.

Hasil evaluasi menunjukkan bahwa UKM membutuhkan: (i) program fasilitasi dan penyediaan kemudahan dalam formalisasi usaha bagi UKM melalui pemenuhan hak-hak legal; (ii) program pengembangan sistem pendukung usaha UKM juga diperlukan, misalnya melalui perluasan sumber pembiayaan, dan penguatan jaringan pasar domestik produkproduk UKM; dan (iii) program penyediaan sistem insentif dan pembinaan untuk memacu pengembangan wirausaha baru UKM

\section{SARAN}

Berdasarkan hasil dari pengabdian dan melihat beberapa hal yang masih perlu dilakukan untuk pemberdayaan perempuan penggerak UKM, saran untuk kegiatan pengabdian ke depan adalah:

a) Perlu dilakukan kegiatan lanjutan dengan melibatkan instansi-instansi baik di tingkat desa, kecamatan ataupun kabupaten agar terjadi kerjasama lintas sektoral yang saling berkesinambungan untuk mengoptimalkan pemberdayaan ekonomi bagi UKM guna meningkatkan kesejahteraan kelompok usaha kecil.

b) Perlu disusun program-program indikatif yang mempercepat peningkatan ekonomi bagi UKM.

c) Pemerintah Kabupaten Semarang perlu terus melakukan upaya sosialisasi, fasilitasi, bimbingan, dan pendampingan dalam pengelolaan UKM

\section{UCAPAN TERIMA KASIH}

Kami atas nama tim pengabdi mengucapkan banyak terimakasih kepada seluruh anggota UKM "Jahit Mandiri" Desa Jetis Kecamatan Bandungan 
Kabupaten Semarang yang telah

memberikan berkenan menerima dan

memberikan informasi berkaitan dengan

pelaksanaan pengabdian ini.

\section{DAFTAR PUSTAKA}

Arminsyurita, A. (2014). Analisis Strategi

Pemasaran Jamur Rimba Jaya

Mushroom. Transparansi Jurnal

Ilmiah Ilmu Administrasi, 6(2),

156-168.

https://doi.org/10.31334/trans.v6i2. 39

BPS Semarang. (2015). Produk Domestik

Regional Bruto Menurut Lapangan

Usaha Kabupaten Semarang 2011-

2015.

https://semarangkab.bps.go.id/publi

cation/2017/08/15/f3682051f71f9e9

11a907e9f/produk-domestik-

regional-bruto-menurut-lapangan-

usaha-kabupaten-semarang--2011-

2015.html

BPS Semarang. (2016). Kabupaten

Semarang dalam Angka 2016.

Semarang. Badan Pusat Statistik.

Friedmann, J. (1992). Empowerment: The politics of alternative development. Blackwell.

Hanim, A. (2015). Evaluasi Kesiapan

UKM Menyongsong Pasar Bebas

Asean (Afta 2003): Suatu Analisis

Perspektif dan Tinjauan Teoritis.
Indiworo, H. E. (2016). Peran perempuan

dalam meningkatkan kinerja

UMKM. EQUILIBRIA

PENDIDIKAN: Jurnal Ilmiah

Pendidikan Ekonomi, 1(1), 40-58.

Putri, L. I. (2017). Reduksi Kemiskinan

Melalui Sosiopreneurship. Islamic

Review: Jurnal Riset dan Kajian

Keislaman, 6(1), 48-68.

https://doi.org/10.35878/islamicrevi

ew.v6i1.117

Saputra, M. H. (2015). Membangun

Kesiapan Usaha Kecil dan

Menengah (UKM) Di Purworejo

Menyongsong Era Masyarakat

Ekonomi ASEAN (MEA).

SEGMEN Jurnal Manajemen dan

Bisnis, 11(3).

Sedyastuti, K. (2018). Analisis

Pemberdayaan UMKM dan

Peningkatan Daya Saing Dalam

Kancah Pasar Global. INOBIS:

Jurnal Inovasi Bisnis dan

Manajemen Indonesia, 2(1), 117-

127.

Soemarwoto, O. (2016). Ekologi,

lingkungan hidup dan

pembangunan. Djambatan.

Yuniasari, D. R., Taufiq, A., \& Herawati,

N. R. (2018). Peran Dinas Tenaga

Kerja, Perindustrian, Koperasi dan

UKM dalam Pemberdayaan

UMKM Sentra Tas di Desa Loram 
Kulon Kecamatan Jati Kabupaten

Kudus. Journal of Politic and

Government Studies, 7(3), 1-10.

https://ejournal3.undip.ac.id/index.p

hp/jpgs/article/view/21108 